\title{
The Impact of Job Enrichment on Employees' Performance: A Survey Study on Jordan Customs Employees in Aqaba
}

\author{
Saud Saleh Abu Tayeh ${ }^{1}$ \\ ${ }^{1}$ Islamic International University / College of Business, Jordan \\ Correspondence: Saud Saleh Abu Tayeh, Islamic International University / College of Business, Jordan. E-mail: \\ tayeh92009@gmail.com
}

Received: June 27, 2020

Accepted: September 9, 2020

Online Published: February 3, 2021

doi:10.5539/ijbm.v16n3p1

URL: https://doi.org/10.5539/ijbm.v16n3p1

\begin{abstract}
The research aimed to identify the role of job enrichment with dimensions (diversity of skills, autonomy, and feedback), on job performance of the administrative employees at Aqaba Jordan customs. The study population consisted of all 213 administrative employees. The researcher applied the descriptive- analytical approach, where questionnaire forms were distributed to a random sample of 138 employees, while131 forms were responded by a response rate of $94.9 \%$. SPSS was applied to analyze data. The study concluded that there was a positive significant relationship between the dimensions of job enrichment and job performance of employees at Aqaba Jordan Customs, which confirms the need to pay more attention to this administrative approach in order to improve the level of job performance of employees in organizations in general
\end{abstract}

Keywords: job enrichment, diversity of skills, job autonomy, job feedback, and employee performance

\section{Introduction}

The success of any organization depends on its human resources, through their skills and capabilities that they have, which in turn enable them to obtain a good competitive position among competitors. Human resources are one of the most important assets in the organization, through which the desired goals, profits are achieved and performance level is improved (Hirbawi, 2019).

The concept of job enrichment is applied by increasing the number of tasks and duties that an employee perform, without the need to increase the work hours, so the goal of enrichment is to get rid of the repetitive routine and avoid indifference.

Job enrichment focuses on creating greater diversity in the content of tasks, and a higher level of know how and skills. In addition, individuals have greater autonomy and responsibility in various fields, all of which lead to getting more useful and meaningful experience. (Bakri, 2015).

This concept has become the main tool, that plays a very important role in improving the level of employees' performance, where it contributes very significantly to achieving growth for the entire organization. Therefore, the employee becomes subject to more attractive job situations, and has a sense of responsibility, since the organizations in the modern era are gradually shifting from considering capital as a major stimulus for job enrichment, to move to work itself as a meaningful value. In this sense, employees accomplish their tasks with an inner spirit emanating from their adherence and loyalty to work more than any external incentives that may be granted to them (Al-Khayat, 2017).

Job enrichment is one of the administrative inputs that enable employees add new resources of satisfaction to a job that increases responsibility, autonomy, control and the level of employee performance (Allemon, 2019).

Job enrichment is defined as the creation of changes in the dimensions of the job, the physical conditions of the job and the basic tasks in order to increase job satisfaction for the individual who is responsible for doing his/her duties.

Job enrichment is also defined as an essential tool used by the administration to increase the motivation of individuals towards better performance, through driving employees to do additional work in order to increase excitement and challenge (Salau et al., 2014).

The studies have shown that the increase in job enrichment and its dimensions among employees enhances and 
improves the level of job motivation. Job enrichment means redesigning jobs in a way that increases the employee's chances to experience feelings of responsibility, achievement, growth and recognition (Davoudi \& Mehdi, 2013).

Aninkan (2014) indicated that job enrichment provides more diversity of skills, autonomy and feedback, as well as giving employees more responsibilities that require them to make decisions, such as job scheduling, defining methods of work and quality.

Self-enrichment also increases self-fulfillment, control and esteem of employees, therefore job enrichment in the organization must be well and soundly managed to ensure the staff's role in improving both individual and organizational performance (Supriya Choudhary, 2016).

There are components that should be included in the job, in order to be considered as an enriched job, according to the theory of job characteristics. As stated in many studies, in order for a job to be described as enriched, it must have a five-dimensional job enrichment that is: multitasking, task identity, mission importance, autonomy, and feedback( Neyshabor \& Parvin, 2013). On the other hand, Customs department is an authority which is responsible for collecting fees and controls the flow of goods, transportation, personal items, and dangerous goods, both inside and outside the country. (World Customs Organization, 2015).

Traditionally, customs are considered the financial body that imposes customs duties and other taxes on import or export. In recent decades, views on the functions of the customs has been expanded to a large extent, and now it covers three basic issues: taxes, security and trade facilitation (Kormych, 2018).

Jordan Customs is considered an economic organization that monitors trade on the border, collects taxes on imports, and plays an important role in supporting the national economy, in terms of attracting investors, protecting the domestic production and fighting the smuggling operations in land, sea and air ports.

There are now The number 22 customs centers in Jordan. Therefore, job enrichment has a critical role in enhancing the efficiency of its human resources, creating and increasing value added, competitiveness and enhancing employee performance. (Jordan Customs 2020).

\subsection{Research Questions}

The study main questions are:

What is the impact of job enrichment with combined dimensions (skills diversity, job autonomy, and job feedback) on job performance of Aqaba Jordan Customs?

\subsection{Research Importance}

The importance of the current research lies in its additions at several levels, which are:

- Academic importance: This research will contribute to increasing knowledge related to job enrichment with its dimensions and impact on employee performance, based on the results concluded on the importance of job redesign and enrichment in developing and increasing the level of performance of its employees.

- importance of customs: It is a department of an economic nature that monitors trade exchanges at the borders, collects taxes on imports, and plays an important role in supporting the national economy, in terms of attracting investors, protecting the domestic product and fighting smuggling operations in land, sea and air ports. It is also authorized to ensure that the countrv is nrotected from transporting prohibited and harmful materials, and by controlling the transit of goods and individuals.

\subsection{Research Model and Hypotheses}

- The Model:

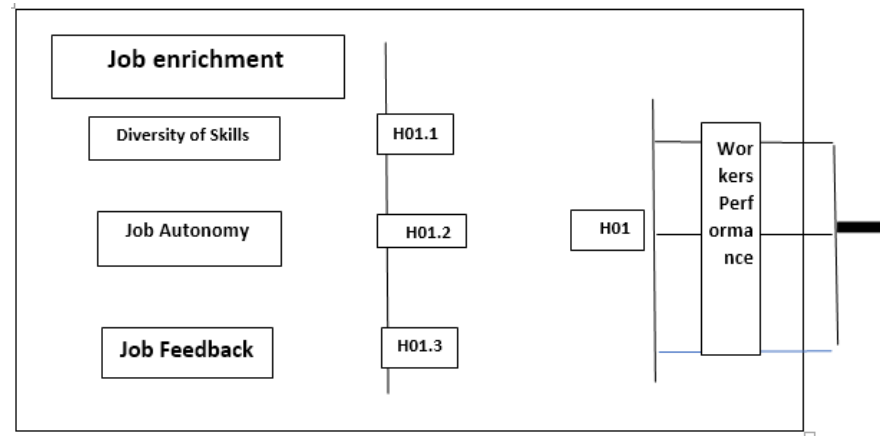

Figure 1. Research model 


\subsection{Research Hypotheses}

- The main hypothesis:

H01: There is no statistically significant impact at $(\alpha \leq 0.05)$ of job enrichment with its dimensions (multi-skills, job autonomy, and job feedback) on the performance of employees at Aqaba Jordan Customs.

Sub-hypotheses

H01.1: There is no statistically significant impact at $(\alpha \leq 0.05)$ of job enrichment dimension of (multi-skills) on the performance of employees at Aqaba Jordan.

H01.2: There is no statistically significant impact at $(\alpha \leq 0.05)$ of job enrichment dimension (job autonomy) on the performance of employees at Aqaba Jordan

H01.3: There is no statistically significant impact at $(\alpha \leq 0.05)$ of job enrichment dimension (job Feedback) on the performance of employees at Aqaba Jordan

\subsection{Research Limits}

Time Limits: Research was applied in the second semester of the academic year 2019-2020

Spatial limits: The research was applied only on the employees of Aqaba Jordan Customs:

\section{Previous Studies}

Allemon (2019) aimed to analyze the effect of job enrichment to achieving the motivation for accomplishment among administrative employees in Arab Potash Company. A questionnaire was developed to collect and analyze data. The study sample consisted of 146 administrative employees, while it applied the descriptive analytical method. This study concluded several results indicated that the perceptions of respondents towards job enrichment and achievement motivation obtained a high degree, so it recommended making efforts to strengthen and maintain this high degree, as well as, conducting more research.

Al-Harbawi (2019) aimed to recognize the extent of the Hebron municipality's application of the concept of job enrichment and career expansion, in addition to determining whether there are differences in the application of job enrichment and expansion attributed to gender, educational qualification, experience, and job level. The study used the descriptive analytical method in collecting and analyzing data through preparing a questionnaire designed for this purpose, while a random sample of 127 employees was selected. The study concluded that the application of the concept of job enrichment in the municipality was accomplished highly.

Al-Khayyat (2017) aimed to find out the relationship between job enrichment and motivity among university employees, and detection of the differences in the components of job enrichment and the level of motivity attributed to gender and job level. The study sample consisted 170male and 130 female employees. The study indicated a positive correlation between job enrichment and motivity, where it showed that enrichment and motivitywere affected by the employee's gender in favor of female employees.

Bakri (2015), aimed to identify the role of components of job enrichment (diversity of skills, job distinction, autonomy, feedback, importance of tasks) in raising the level of job performance for administrative staff at the Islamic University of Gaza. The study population consisted of all 452 university employees, while a sample of (203) was selected using a stratified random sample. The questionnaire was used as a tool to collect data, which was analyzed using SPSS. The study adopted the descriptive approach, and concluded the following results:

1. There is a statistically significant positive relationship between the dimensions of job enrichment, individually and collectively, and job performance.

2. The level of job enrichment at the Islamic University has a high rate and relative weightof $81 \%$.

3. The level of job performance of employees at the Islamic University has a high rate and relative weight of $80.45 \%$.

Kormych (2018) study aimed at determining the basic shifts in global and international trade standards, which reflected its impact on the work of customs authorities and change in border procedures between countries. It discussed the procedures of the World Trade Organization and its role in simplifying procedures between countries, and clarity of customs tasks concerned with collecting revenues. The findings focused on the concept of good governance and activating the single window system.

Marta and Supartha (2018) study aimed to find out the impact of job enrichment and employee empowerment on the organizational commitment of employees in the regional office in Bali and Noosa. It applied the questionnaire to collect data and information for all42 employees, who occupy executive positions. It found that job enrichment 
and empowerment affect significantly and directly the process of organizational commitment, and recommended taking into account the size of work done by the employee, and focus on the size of the compensation against this work.

Hope et al. (2017) study aimed to determine the impact of job enrichment on job commitment in some manufacturing firms in Nigeria. It was conducted on a sample of 156 employees. among the population of 543 employees. The study concluded that there was a positive significant relationship between job autonomy and the emotional commitment of employees. It recommended that organizations should focus on giving employees some level of autonomy.

Devia et al. (2016) study aimed to explore the effect of job enrichment dimensions (Task importance, identity of the task, and diversity of skills) on the performance of employees in selected companies of IT Industry. The study adopted the descriptive-analytical approach in a random sample of 151 employees. The study indicated that job enrichment affects significantly the improvement of employee performance, and that the dimension of task identity was the most significant one among all dimensions.

\section{Research Methodology}

The analytical descriptive approach was used for the current research to match the nature and conditions of collecting accurate academic descriptions of the status quo of phenomenon under study by using initial assumptions

\subsection{Research Population and Sample}

The population consisted of all 213 administrative staff of Aqaba Jordan Customs. To achieve the research goals, a random sample of 138 employees was selected where the study questionnaire was distributed to them, while the responded forms were 135 and 4 forms were ignored, by a response rate of 94.9 as shown in Table 1.

Table 1. Distribution of demographic data of respondents

\begin{tabular}{lllll}
\hline Variable & Segment & freq & $\%$ & Total \\
\hline \multirow{2}{*}{ gender } & male & 82 & 62.6 & \multirow{2}{*}{131} \\
& female & 49 & 37.4 & \\
Age segment & $20-29$ & 64 & 48.9 & \\
& $30-39$ & 49 & 37.4 & 131 \\
& $49-49$ & 10 & 7.6 & \\
experience & $>50$ & 8 & 6.1 & \\
& $<5$ & 62 & 47.3 & \\
& $5-9$ & 33 & 25.2 & \multirow{2}{*}{131} \\
& $10-15$ & 23 & 17.6 & \\
qualifications & $>15$ & 13 & 9.9 & \\
& diploma & 20 & 15.3 & \\
& Bachelor & 91 & 69.4 & \multirow{2}{*}{131} \\
& Masters & 13 & 9.9 & \\
\hline
\end{tabular}

The results show that $(62.6 \%)$ of respondents were males, and (37.4\%) were females. Those of age segment (20 $29)$ represented $(48.9 \%$, followed by the segment of $(30-39)$ by $(37.4 \%)$, while the segment of $(40-49)$ obtained $(7.6 \%)$, and finally the segment of (50 years and over) obtained $(6.1 \%)$ of the sample.

With regard to the number of years of experience, the results showed that the segment of employees with less than 5 years obtained $47.3 \%$, followed by the segment of (10-15) years by $25.2 \%$, while the segment of 15 years or more obtained $9.9 \%$.

For educational level, individuals who have a bachelor degree obtained $69.4 \%$, followed by diploma or less holders by $15.3 \%$ and finally those with a master's and doctorate degree obtained (9.9\%), (5.3\%), respectively.

\subsection{Research Instrument}

A questionnaire was prepared by the researcher, based on the theoretical framework and previous studies, consisted of 30 items, distributed among job autonomy which was measured by 9 items, job feedback which was measured by 7 items and job enrichment, measured with 4 items. 


\subsection{Reliability of the Research Instrument}

Coefficient of instrument internal consistency Cronbach's Alpha was calculated as shown in table 2. The Cronbach coefficient $\alpha$ has a range value (0.816-0.775) for job enrichment. For the dimensions of dependent variable the coefficient was 0.815 job performance. It is noted here that all values of stability parameter exceeded the accepted minimum limit of 0.7 . This indicates that the research instrument has a statistically acceptable stability coefficient, and the reliability of the results that the instrument produces can be trusted when applied.

Table 2. Internal consistency coefficients - Cronbach $\alpha$ for resolution

\begin{tabular}{llll}
\hline Variable & Dimension & Items & Cronbach Alpha $\alpha$ \\
\hline \multirow{3}{*}{ Job Enrichment } & Diversity of skills & $1-10$ & 0.792 \\
& Job Autonomy & $11-19$ & 0.816 \\
& Job feedback & $20-26$ & 0.775 \\
& Employee Performance & $27-30$ & 0.815 \\
\hline
\end{tabular}

\section{Results and Discussion}

To achieve goal, the mean, standard deviation, rank and assessment score for each dimension of the instrument, and for the instrument as a whole, were calculated, as shown in the tables below.

\subsection{The Diversity of Skills}

Table3. Arithmetic means and standard deviations for multi-skill items

\begin{tabular}{|c|c|c|c|c|c|}
\hline No & Item & Mean & Std.dev & Rank & Assess \\
\hline 1 & $\begin{array}{l}\text { I am allowed to use different types of skills to Implement } \\
\text { my tasks }\end{array}$ & 3.94 & 1.021 & 5 & high \\
\hline 2 & I usually fulfill my tasks & 3.95 & 0.960 & 2 & high \\
\hline 3 & Jordan Customs recognizes and appreciates my efforts & 3.86 & 0.959 & 7 & high \\
\hline 4 & I have the necessary skills to do my duties & 3.78 & 0.939 & 8 & high \\
\hline 5 & I can handle the techs and software necessary for my job & 3.76 & 0.985 & 9 & high \\
\hline 6 & I do my tasks in the specified time & 3.94 & 0.901 & 3 & High \\
\hline 7 & Sometimes my manager assigns me additional tasks & 4.00 & 0.920 & 1 & high \\
\hline 8 & $\begin{array}{l}\text { Variation of skills and tasks contributes to increasing my } \\
\text { performance }\end{array}$ & 3.94 & 0.967 & 4 & high \\
\hline 9 & $\begin{array}{l}\text { Jordan Customs sets the necessary training programs to } \\
\text { develop my skills and capabilities }\end{array}$ & 3.90 & 0.910 & 6 & High \\
\hline 10 & $\begin{array}{l}\text { I am allowed to use different types of skills to fulfill my } \\
\text { task }\end{array}$ & 3.70 & 0.838 & 10 & High \\
\hline \multicolumn{2}{|c|}{ Total average mean } & 3.87 & high & & \\
\hline
\end{tabular}

Table 3 indicates that item 7 "Sometimes my manager assigns me additional tasks" obtained the first rank with a high assessment with a mean of 4.00 and standard deviation of 0.920. Item 10" I am allowed to use different types of skills to fulfill my task" obtained the last rank with mean of 3.70 and Standard deviation of 0.838 . 


\subsection{Job Autonomy}

Table 4. Arithmetic mean and standard deviations for job autonomy items

\begin{tabular}{|c|c|c|c|c|c|}
\hline No & Item & Mean & Std.dev & Rank & Assess \\
\hline 11 & $\begin{array}{l}\text { I am free to decide the best approach to implement my } \\
\text { task }\end{array}$ & 3.82 & 0.924 & 5 & high \\
\hline 12 & $\begin{array}{l}\text { I implement my tasks without asking permission from my } \\
\text { direct manager }\end{array}$ & 3.75 & 0.923 & 9 & high \\
\hline 13 & $\begin{array}{l}\text { My job enables me to use my personal know how when } \\
\text { doing my task }\end{array}$ & 3.92 & 0.877 & 3 & high \\
\hline 14 & I choose the method to do my task freely & 3.76 & 0.912 & 8 & high \\
\hline 15 & $\begin{array}{l}\text { I am independent when doing my job despite other } \\
\text { responsibilities and tasks assigned to me }\end{array}$ & 3.89 & 0.982 & 4 & high \\
\hline 16 & $\begin{array}{l}\text { Management focuses on staff participation in making } \\
\text { decisions }\end{array}$ & 3.98 & 0.953 & 1 & High \\
\hline 17 & $\begin{array}{l}\text { Flexible hierarchy of Jordan Customs leads to success of } \\
\text { achievement }\end{array}$ & 3.94 & 0.934 & 2 & high \\
\hline 18 & $\begin{array}{l}\text { My job autonomy provides me with opportunity to do my } \\
\text { tasks properly }\end{array}$ & 3.79 & 0.942 & 6 & high \\
\hline 19 & $\begin{array}{l}\text { My job autonomy and flexibility help increasing } \\
\text { performance }\end{array}$ & 3.79 & 0.961 & 7 & High \\
\hline \multicolumn{2}{|c|}{ Total average mean } & 3.85 & high & & \\
\hline
\end{tabular}

Table 4 shows that item 16 ("Management focuses on staff participation in making decisions" ranked first with a mean of 3.98and standard deviation of .9530 Item 12 "I implement my tasks without reporting my direct manager" got the last rank with a mean of 3.75 and standard deviation) of 0.923

\subsection{Job Feedback}

Table 5. Arithmetic means and standard deviations for job feedback items

\begin{tabular}{|c|c|c|c|c|c|}
\hline No & Item & Mean & Std.dev & Rank & Assess \\
\hline 20 & $\begin{array}{l}\text { My knowledge of the results of my job provides me with } \\
\text { knowledge of my performance }\end{array}$ & 3.98 & 0.953 & 2 & high \\
\hline 21 & $\begin{array}{l}\text { My daily work provides me the opportunity to assess my } \\
\text { performance }\end{array}$ & 3.93 & 0.970 & 3 & high \\
\hline 22 & $\begin{array}{l}\text { Throughout my work I can determine the level of my } \\
\text { performance }\end{array}$ & 3.82 & 0.988 & 5 & high \\
\hline 23 & $\begin{array}{l}\text { Jordan Customs provide the staff with dail reports that } \\
\text { assess their performance }\end{array}$ & 3.91 & 0.898 & 4 & high \\
\hline 24 & Results of feedback are the basis of decision taking & 3.78 & 0.979 & 6 & high \\
\hline 25 & Employees get the comments regularly & 4.01 & 0.846 & 1 & High \\
\hline 26 & $\begin{array}{l}\text { Process of control and assessment encourages the } \\
\text { required feedback }\end{array}$ & 3.70 & 0.926 & 7 & high \\
\hline \multicolumn{2}{|c|}{ Total average mean } & 3.88 & high & & \\
\hline
\end{tabular}

Table5indicates that item 25 "Employees get the comments regularly" ranked first in a high assessment degree with an arithmetic mean of 4.01 and a standard deviationof.846, while item 26 "Process of control and assessment encourages the required feedback" ranked the last with a high assessment and an arithmetic mean of 3.70 and Standard deviation of.9260. All items of this dimension obtained high assessment 


\subsection{Impact of Job Enrichment Dimension on the Performance of Employees}

Table 6. Arithmetic means and standard deviations of the employment enrichment impact on employee performance

\begin{tabular}{|c|c|c|c|c|c|}
\hline No & Item & Mean & Std.dev & Rank & Assess \\
\hline 27 & $\begin{array}{l}\text { Job enrichment makes me feel responsible for and } \\
\text { appreciation of my job and its results }\end{array}$ & 3.88 & 0.945 & 1 & high \\
\hline 28 & $\begin{array}{l}\text { Job enrichment encourages me to raise my motivity and } \\
\text { job satisfaction }\end{array}$ & 3.76 & 0.993 & 3 & high \\
\hline 29 & $\begin{array}{l}\text { My multi skills, autonomy and feedback help improve } \\
\text { my performance }\end{array}$ & 3.75 & 1.040 & 4 & high \\
\hline 30 & $\begin{array}{l}\text { In general job enrichment makes me do the tasks in a high } \\
\text { quality performance }\end{array}$ & 3.79 & 1.006 & 2 & high \\
\hline \multicolumn{2}{|c|}{ Total average mean } & 3.79 & high & & \\
\hline
\end{tabular}

Table 6 shows that item 27 "Job enrichment makes me feel responsible for and appreciation of my job and its results" ranked first with a high rating and a mean of 3.88and Standard deviation of.945. Item 29" My multi skills, autonomy and feedback help improve my performance "with a high rating and a mean of 3.75 and a standard deviation of 1.040 . All items of this dimension got a high rate.

\subsection{Hypotheses Test}

The main hypothesis

H01: There is no statistically significant impact at $(\alpha \leq 0.05)$ of job enrichment with its dimensions (multi-skills, job autonomy, and job feedback) on the performance of employees at Aqaba Jordan Customs.

Table 7. Multiple regression analysis of the impact of job enrichment on employee performance

\begin{tabular}{lllllllllll}
\hline Dependent Var & $\mathrm{R}$ & $\mathrm{R}^{2}$ & $\mathrm{~F}$ & $\mathrm{Sig}^{*}$ & Indep. Dim & $\mathrm{B}$ & $\mathrm{S} . \mathrm{E}$ & $\mathrm{Beta}$ & $\mathrm{T}$ & Sig* \\
\hline & & & & & Multi skills & -0.047 & 0.117 & 0.045 & -0.405 & 0.686 \\
& & & & & Autonomy & 0.468 & 0.124 & 0.441 & 3.783 & 0.000 \\
Employee Performance & $0.693 \mathrm{a}$ & 0.480 & 39.071 & $0.000 \mathrm{~b}$ & feedback & 0.400 & 0.089 & 0.367 & 4.507 & 0.000 \\
\hline
\end{tabular}

Note. * Statistically significant Impactat $\alpha \leq 0.05$.

Table 7 shows the impact of job enrichment dimensions (diversity of skills, job autonomy, job feedback) on the performance of employees at Aqaba Jordan Customs. The results indicated a statistically significant impact of job enrichment dimensions on employee performance, where it was observed that the correlation coefficient $\mathrm{R}$ was 0.693 at $\alpha \leq 0.05$. The regression coefficient $R^{2}$ was 0.480 , which indicates that $48 \%$ of the change in the employees performance was a result of the change in the dimensions of job enrichment with their dimensions combined. This impact confirmed the value $F$ Calculated that was 39.071 at $\alpha \leq 0.05$. This leads to the rejection of the main hypothesis.

The results also indicated that the highest impact was attributed to the autonomy of the employees performance where Coefficient of regression was 0.441 with $t$ value of 3.783 and level of significance of $(0.000)$, which means it is significant

The next dimension is job feedback impact the performance of employees where Regression coefficient $\boldsymbol{R}^{2}=0.367$ with $t$ value $=4.507$ and significance degree $=0.000$, which means it is significant.

Finally, the diversity of skills impact on the performance of employees where Regression coefficient $\boldsymbol{R}^{2}=0.045, \mathrm{t}$ value $=0.405$ and significance degree $=0.686$ which is insignificant.

Therefore, the null hypothesis was rejected, and the alternative was accepted, which states that "there is a statistically significant impact, at ( $\alpha \leq 0.05$ ), of job enrichment in terms of its dimensions (diversity of skills, job autonomy, job feedback) on the performance of employees at Aqaba Jordan Customs.

H01-1: There is no statistically significant impact, at $(\alpha \leq 0.05)$ of skills diversityon the performance of employees at Aqaba Jordan Customs. 
Table 8. Multiple regression analysis of the impact of multiple skills on employee performance

\begin{tabular}{lllllllllll}
\hline Dependent Var & $\mathrm{R}$ & $\mathrm{R}^{2}$ & $\mathrm{~F}$ & $\mathrm{Sig} *$ & Indep. Dim & $\mathrm{B}$ & $\mathrm{S} . \mathrm{E}$ & Beta & $\mathrm{T}$ & Sig* $^{*}$ \\
\hline Employee Performance & $0.517 \mathrm{a}$ & 0.267 & 47.020 & $0.000 \mathrm{~b}$ & Multi skills & 0.545 & 0.080 & 0.517 & 6.857 & 0.000 \\
\hline Note. * & Statistically significant effect at the significance level $\alpha \leq 0.05$. & & & & & &
\end{tabular}

Table 8 shows the impact of multiple skills on the performance of employees at Aqaba Jordan Customs, where the results indicated that the correlation coefficient $\mathrm{R}=0.517$ at $\alpha \leq 0.05$ and the regression coefficient $\mathrm{R}^{2}=.267$, which indicates that the value of $t$ explains $(26.7 \%)$ of the change in the performance factor resulting from the change in the dimensions of the diversity of skills, and stressed that the impact of the value of $F$ Calculated $=$ 47.020 , at $\alpha \leq 0.05$. while the results of the analysis indicate that $\mathrm{B}=0.545$ and $\mathrm{t}=6.857$ with significance level $=$ 0.000 which leads to rejection of the first sub null hypothesis, and the acceptance of the alternative hypothesis which states that" there is a statistically significant impact at the level of significance $(\alpha \leq 0.05)$ of the diversity of skills on the performance of employees at Aqaba Jordan customs", was accepted.

H01-2: There is no statistically significant impact, at $(\alpha \leq 0.05)$ of job autonomy on the performance of employees at Aqaba Jordan Customs.

Table 9. Multiple regression analysis of the impact of job autonomy on employee performance

\begin{tabular}{lllllllllll}
\hline Dependent Var & $\mathrm{R}$ & $\mathrm{R}^{2}$ & $\mathrm{~F}$ & Sig* & Independent Dim & $\mathrm{B}$ & $\mathrm{S} . \mathrm{E}$ & Beta & $\mathrm{T}$ & Sig* $^{*}$ \\
\hline Employee Performance & $0.630 \mathrm{a}$ & 0.397 & 84.832 & $0.000 \mathrm{~b}$ & Multi skills & 0.668 & 0.073 & 0.630 & 9.210 & 0.000 \\
\hline
\end{tabular}

Note. * Statistically significant impact at the significance level $\alpha \leq 0.05$

The table shows the effect of job autonomy on the performance of employees in Aqaba Jordan Customs, where the results indicated that the correlation coefficient $\mathrm{R}=.630$, at $\alpha \leq 0.05$, and the regression coefficient $\mathrm{R}^{2}=0.397$, which indicates that the values $t=39.7 \%$ of the change in the performance of employees resulting from the change in job autonomy, and confirmed the impact of the value of calculated $F=84.832$, at the level $\alpha \leq 0.05$, while the results show that the Regression coefficient $B=6680, t$ value $=9.210$ and the significance level $=0.000$. Therefore, the hypothesis was rejected and the alternative one, which states that "there is a statistically significant impact at $(\alpha \leq 0.05)$ of job autonomy on the performance of employees at Aqaba Jordan Customs," was accepted.

H01-3 There is no statistically significant impact, at $(\alpha \leq 0.05)$ of job feedback on the performance of employees at Aqaba Jordan Customs.

Table 10. Multiple regression analysis of the impact of job feedback on employee performance

\begin{tabular}{lllllllllll}
\hline Dependent Var & $\mathrm{R}$ & $\mathrm{R}^{2}$ & $\mathrm{~F}$ & $\mathrm{Sig} *$ & Independent Dim & $\mathrm{B}$ & $\mathrm{S} . \mathrm{E}$ & $\mathrm{Beta}$ & $\mathrm{T}$ & Sig* $^{*}$ \\
\hline Employee Performance & $0.613 \mathrm{a}$ & 0.376 & 77.612 & $0.000 \mathrm{~b}$ & Multi skills & 0.667 & 0.076 & 0.613 & 8.810 & 0.000 \\
\hline
\end{tabular}

Note. *Statistically significant effect at the significance level $) \alpha \leq 0.05$.

The table shows the effect of job feedback on the performance of employees in Aqaba Jordan Customs, where the results indicated that the correlation coefficient $\mathrm{R}=.613$, at the significance level $\alpha \leq 0.05$, and the regression coefficient $\mathrm{R}^{2}=0.376$, which indicates that the values $\mathrm{t}=37.6 \%$ of the change in the performance of employees resulted from the change in job feedback, and confirmed the impact of the value of calculated $F=77.612$ at $\alpha \leq$ 0.05 , while the results show that the Regression coefficient $\mathrm{B}=667, \mathrm{t}$ value $=8.810$ and the significance level $=0.000$.

Therefore, the hypothesis was rejected and the alternative one, which states that" there is a statistically significance at $(\alpha \leq 0.05)$ of job feedback on the performance of employees at Aqaba Jordan Customs" was accepted.

\section{Conclusions and Recommendations}

The aim of the research was to determine the impact of job enrichment with its dimensions (diversity of skills, job autonomy, and job feedback) on the performance of employees at Aqaba Jordan Customs, and based on the theoretical and experimental results here are the following conclusions:

1. There is a positive significant statistical relationship between job enrichment and employees' performance at 
Aqaba Jordan Customs, where the researcher suggests that this result is attributed to the fact that, if the employees have diversity of skills that can be relied upon when needed, it will lead to best performance especially when they feel that they are integral part of the decision - making process and when they receive the job feedback regularly.

2. There is a positive significant relationship between the diversity of skills and performance of employees at Aqaba Jordan Customs. The researcher suggests it is attributed to the fact that with better and developed skills of employees they may be able to perform their jobs in a better way, and will allow them to deal with technological changes in their field, which will lead to a high level of job performance.

3. There is a positive significant relationship between job autonomy and the performance of employees at Aqaba Jordan Customs which indicates that employees have the ability to perform some tasks in the way they prefer; to some extent, they have the autonomy to make decisions through the power they are authorized.

4. There is a positive significant relationship between job feedback and the performance of at Aqaba Jordan Customs, since feedback will allow them to determine the weakness and develop their strengths which leads to a better employee and better performance.

Based on the research results, discussion and conclusions, the researcher proposes the following recommendations:

1. job enrichment dimensions should be taken into consideration when Customs Department take decisions on creating new Jobs or developing the current hierarchy, because the more the jobs are enriched the better performance of the employees will be done since employees will get diverse skills and acquire a sense of autonomy as they do, and feel as integral part of decision makers.

2) The researcher recommends that Jordan Customs should have a continuous process to redesign the jobs and the job location, which can be done by establishing a system that requires employees, supervisors and specialized committees to provide inputs related to changes in the environment and new technologies, and to determine what new skills, capabilities and competencies are necessary to perform the jobs effectively.

3. There is a need to empower employees by giving them more opportunity in the decision-making process, not by requiring them to participate and through delegation only, but also by including their participation in decision-making processes effectively and efficiently.

4. pay more attention to the processes of job feedback to assure that they are in a regular basis through reports and performance assessments, and to give employees opportunity for self-assessment to determine and identify the skills type they need here to develop themselves.

5.show appreciation and respect to employees efforts through bonuses and incentives systems, moral, honor and expressions of thanks and gratitude to make them feel the right role in the organization which will reflect on their performance.

\section{References}

Al-Harbawi, M. (2019). Extent of application of job enrichment and job expansion in the Hebron municipality. Unpublished Master Thesis, College of Graduate Studies, Hebron University, Palestine.

Al-Khayat, M. (2017). The relationship between job enrichment and motivity among the employees of Al-Balqa Applied University: a survey study of university main campus staff. Najah University Journal for Research (Humanities Sciencies), 31(8).

Allemon, B. (2019). The effect of job enrichment on achieving motility for accomplishment among the employees of Arab Potash Company: a case study. Unpublished Master Thesis, Mu'tah University, Faculty of Economics, Amman, Jordan.

Aninkan, D. O. (2014). The Impact of Reward Management and Job Enrichment on Job Satisfaction among Employees in the Ogun State Polytechnics. International Journal of Business and Management Invention, 3(3), 19-26.

Bakri, Z. A. (2015). The effect of job enrichment on the performance of administrative staff: A Case study. Unpublished Master Thesis, College of Commerce / Department of Business Administration, Islamic University, Gaza, Palestine.

Davoudi, S., \& Mehdi, M. (2013). Impact of job Enrichment on Organizational Citizenship Behavior. SCMS Journal of Indian Management, 10(2), 106-112.

Divya, S., Pujar, S. R., \& Sangeetha, K. (2016). Job Enrichment and Its Impact on Employee Performance in it Industry. Asia Pacific Journal of Research, 1(XLIV), 162-169. 
Hope, N. N., Obianuju, M. C., Obi, E., Agu, E. R., \& Augustine, A. E. (2017). Job Enrichment and Employee Commitment in Selected Brewing Firms in Anambra State. Saudi Journal of Business and Management Studies, 2(4), 330-337.

Kormych, B. (2018). The modern trends of the foreign trade policy implementation for customs regulations. Lex, $5(5), 27-45$.

Neyshabor, A., \& Rashidi, P. (2013). An Investigation of the Relationship between Job Enrichment and Organizational Commitment. International Journal of Research in Organizational Behavior and Human Resource Management, 1(3), 57-65.

Salau, O., Adeniji, A., \& Oyewunmi, A. (2014). Relationship between Components of Job Enrichment and Organization Performance among the Non-Academic Staff in Nigeria Public Universities. Management \& Marketing, 12(2), 173-189.

Supriya, C. (2016). Job enrichment: A tool for employee motivation. International Journal of Applied Research, 2(5), 1020-1024.

\section{Copyrights}

Copyright for this article is retained by the author(s), with first publication rights granted to the journal.

This is an open-access article distributed under the terms and conditions of the Creative Commons Attribution license (http://creativecommons.org/licenses/by/4.0/). 